\title{
MENGEMBANGKAN KECERDASAN SPIRITUAL ANAK MELALUI PENDIDIKAN AGAMA
}

Yuliyatun

Jurusan Dakwah STAIN Kudus

\begin{abstract}
Naturally, Every child born has brought potential for good, that will foster a sense of potential and needs to know and close to Allah who created him. Communication that is built will bring up commendable attitudes and always incline to virtue. This is the characteristics of spiritual potential that contain high values of humanity. The values will be wise and make coverage always attend deep meaning and value in their actions. Religious education can be used as a medium or tool to a activate children spiritual intelligence potency in addition to their emotional and intelectual ones. This paper analyzes how the importance of religious education which is reinforced by the meaning of each Islamic dimension (faith, Islam, and ihsan) in every facet of human life.
\end{abstract}

Keywords: spiritual intelligence, children, religious education

\section{A Pendahuluan}

Perkembangan ilmu pengetahuan dan teknologi tidak hanya menghasilkan berbagai produk disiplin ilmu yang terspesifikasi secara sempit dan produk teknologi yang menjangkau hampir dalam setiap lini kehidupan manusia. Tetapi juga memunculkan banyak dan beragamnya ambisi dan daya saing yang kuat dalam masyarakat yang membutuhkan kekuatan berpikir, berkreasi, berinovasi, dan berproduksi. Kekuatankekuatan itu sekaligus sebagai ciri dari kehidupan masyarakat modern sebagai upaya penyesuaian diri dalam perkembangan modern yang cukup pesat.

Fenomena tersebut dirasakan juga dalam dunia pendidikan, dimana para orang tua berlomba untuk membekali anak-anaknya dengan beragam kemampuan dan keterampilan yang dianggap sebagai bekal menjadi manusia modern yang mampu bersaing di tengah pesatnya perkembangan 
zaman. Tidak ada buruknya memang ketika kemudian para orang tua dan para pendidik memberikan banyak materi keilmuan dan keterampilan praktis yang kelak diharapkan dapat menghasilkan individu dewasa yang memiliki kecakapan ilmu dan keahlian sesuai dengan bidang konsentrasi pilihannya. Misalnya, menjadi seorang arsitek, lawyer, teknisi, dokter, programer komputer, akuntan, ahli manajemen, ahli fisika, ahli biologi, ahli matematika, pengusaha, dan masih banyak lagi. Lagi pula masing-masing bidang pekerjaan dan keahlian berkembang dari upaya manusia dalam memenuhi kebutuhannya baik lahir maupun batin.

Oleh karenanya, masyarakat berlomba-lomba untuk memasukkan anaknya di sekolah-sekolah favorit yang diharapkan dapat memenuhi harapan akan terbentuknya lulusan yang mampu bersaing di tengah persaingan alam modern. Berbagai les dan kursus pun ditempuh untuk memenuhi kekurangan lembaga-lembaga pendidikan formal yang dianggap masih kurang efektif dalam memberikan materi pelajaran yang dibutuhkan anak. Apalagi dengan adanya standar ujian nasional yang kontroversial di kalangan ahli pendidikan namun tetap berlangsung, akhirnya mendorong para orang tua dan para guru untuk mentargetkan pembelajaran dengan standar nilai ujian kelulusan secara nominal saja. Maka, pembelajaran pun senantiasa berorientasi pada penguasaan secara kuantitas dari materi pelajaran, bagaimana siswa mampu menjawab soal-soal ujian.

Sementara ada sisi kehidupan anak yang lain yang terabaikan, yakni sisi moral spiritual. Persaingan dan ambisi keberhasilan pendidikan selama ini hanya terfokus pada pengembangan kemampuan berpikir secara materialistik-positifistik semata. Pengembangan kemampuan berpikir yang mengedepankan kecerdasan intelektual yang jatuh pada penguasaan secara materi tanpa adanya penghayatan terhadap nilai yang ada dibalik sebuah ilmu dan pengetahuan. Bahkan dalam pengetahuan agama pun, hanya dipahami sebagai sebuah doktrin ajaran dan sekumpulan ritual yang semu. Akibatnya, bentuk-bentuk perilaku, sikap, dan cara berpikir pun tidak mencerminkan nilai moral-spiritual yang merupakan fitrah manusia sebagai makhluk spiritual dengan keberadaan hati nurani (bashar, bagian terdalam dari qalb) sebagai sumber potensi spiritual. Sebagai contoh, anak mudah melakukan kekerasan dalam pergaulan ketika keinginannya tidak terpenuhi, kesalahan anak memahami pergaulan sehingga terjerumus dalam pergaulan bebas dan perilaku seks bebas dan menyimpang, berbagai bentuk kenakalan anak yang suka mengganggu anak lain, berbagai tawuran pelajar, remaja yang suka foya-foya. Atau anak dan remaja yang secara akademis berhasil dalam kecerdasan intelektualnya tetapi kering dari penghayatan nilai.

Fenomena di atas menunjukkan adanya sisi kehidupan manusia 
yang terabaikan dalam proses pendidikan terhadap anak, yakni sisi spiritual. Padahal untuk mampu eksis dalam perkembangan zaman modern tidak hanya dibutuhkan kepintaran, keterampilan, dan keahlian saja, melainkan juga kearifan sikap ketika dihadapkan pada pesatnya perubahan dan membutuhkan penyesuaian diri dengan berbagai kondisi dan lingkungan yang senantiasa berubah. Maka, sangat diperlukan kondisi mental yang kuat yang mampu eksis dengan tetap mempertahankan nilainilai agama dan masyarakat sebagai benteng dari kemungkinan dampak negatif yang ditimbulkan dari perkembangan zaman.

Kemajuan ilmu pengetahuan dan teknologi yang mengabaikan nilai-nilai spiritual hanya menyelesaikan permasalahan secara semu karena acuannya hanya pada permukaan luar dari permasalahan itu sendiri. Penyelesaian masalah yang belum menyentuh sisi terdalam dari eksistensi manusia, sehingga tampak kegelisahan, keputusasaan, rasa ambisius yang berlebihan, serta kompetisi yang tidak sehat dan tidak suportif mengemuka dalam problematika kehidupan modern. Cortright (1997, dikutip dalam Kata Pengantar Rahmat, 2002: xxvi) menulis:

"studi sedalam apapun tentang genetika, biokimia, atau neurologi, pada satu sisi, atau sistem keluarga, interaksi ibu-anak, dan pengalaman masa kecil pada sisi yang lain—atau dengan perkataan lain, tidak ada penjelasan apapun, yang memperhitungkan hanya penampakkan luar dari masalah nature (tabiat) dan nurture (lingkungan)-dapat memberikan jawaban memuaskan pada masalah fundamental kehidupan. Hanya dengan memandang ke dimensi spiritual, yang memasukkan dan sekaligus mentransendenkan warisan dan lingkungan, kita dapat menemukan jawaban yang tepat untuk masalah eksistensi manusia."

Untuk itulah, seorang anak yang masih dalam proses perkembangan sangat membutuhkan bimbingan untuk mengembangkan segala potensi kecerdasan yang secara fitrah telah ada dalam diri setiap anak, baik dari sisi intelektual, emosional, maupun spiritual. Selama ini kecenderungan potensialisasi anak terfokus pada kecerdasan intelektual, sehingga terjadi ketidakseimbangan perkembangan psikis anak dalam sisi emosional dan spiritualnya.

Bahkan dalam kegiatan pendidikan agama pun, cenderung hanya mentargetkan pada penguasaan materi keagamaan tanpa adanya penghayatan nilai-nilai yang terkandung dalam setiap ajarannya. Padahal pendidikan agama seharusnya menjadi sarana utama untuk mempotensikan kecerdasan spiritual anak. Dengan demikian kelak anak akan tumbuh 
menjadi pribadi yang relijius dengan memiliki moral spiritual yang akan menguatkan menjadi seorang abdullah dan seorang khalifah Allah di muka bumi.

Dari latar belakang inilah, penulis tertarik untuk mengangkat tulisan "Mengembangkan Kecerdasan Spiritual Anak melalui Pendidikan Agama". Dengan membaca berbagai literatur dan fenomena yang terjadi dalam masyarakat terutama dalam bidang pendidikan, tulisan ini merumuskan permasalahan tentang konsep kecerdasan spiritual sebagai sebuah potensi, dan bagaimana kiat orang tua atau pendidik dalam mengembangkan potensi kecerdasan spiritual anak.

\section{B. Pembahasan}

\section{Konsep Kecerdasan Spiritual}

Secara terminologi, kecerdasan (intellegence) diartikan sebagai kemampuan individu dalam memahami suatu fenomena secara kritis dan analitis dan menyelesaikan suatu masalah secara tepat dan efektif sehingga mampu menyesuaikan diri dalam berbagai situasi lingkungan. J.P.Chaplin (1999:253) mendefinisikan kecerdasan dalam tiga definisi. Pertama, kemampuan menghadapi dan menyesuaikan diri terhadap situasi baru secara cepat dan efektif. Kedua, kemampuan menggunakan konsep-konsep abstrak secara efektif yang meliputi empat unsur: memahami, berpendapat, mengontrol, dan mengritik. Ketiga, kemampuan memahami pertalian-pertalian dan belajar cepat sekali. Jadi, kecerdasan seseorang dapat dilihat dari kemampuannya dalam memahami konsep-konsep pengetahuan, kemampuannya mengaplikasikan konsep pengetahuan dalam pemecahan suatu persoalan, dan kemampuannya menyesuaikan diri dalam berbagai situasi.

Sementara spiritual, diambil dari kata spirit yang dalam bahasa Inggris diartikan sebagai ruh, jiwa. Istilah spiritual kemudian digunakan dalam peristilahan yang terkait dengan daya atau kekuatan, energi dalam diri individu sehingga memiliki tingkat kualitas kejiwaan yang tinggi. Ya, spiritual selalu dikaitkan dengan kualitas batin, kejiwaan, yang membuat individu mampu memaknai suatu gejala atau fenomena dengan makna dan nilai secara luas. Spiritual meliputi nilainilai luhur, nilai-nilai kemanusiaan, yang manjadikan individu bersikap dan berpikir secara arif dalam mendasari segala tindakannya.

Dalam tradisi Islam, pengertian spiritualitas didasarkan pada konsep penciptaan manusia yang memiliki tugas beribadah kepada Allah swt (QS. adz-Dzariayat:56). Spiritualitas merupakan aspek esoteris Islam yang menjadikan pengalaman batiniyah dan ruhaniyah 
sebagai cara pencapaian kebahagiaan yang hakiki. Seperti yang dipaparkan Allama Mirsa Ali Al-Qadhi, bahwa spiritualitas merupakan tahapan perjalanan batin seorang manusia untuk mencari dunia yang lebih tinggi dengan bantuan riyadahat dan berbagai amalan pengekangan diri sehingga perhatiannya tidak berpaling dari Allah, semata-mata untuk mencapai puncak kebahagiaan abadi (dikutip dalam Ruslan, 2008:16). Ruslan juga mengutip pendapat Hossen Nasr bahwa spiritualitas merupakan sesuatu yang mengacu pada apa yang terkait dengan dunia ruh, dekat dengan Ilahi, mengandung kebatinan dan interioritas yang disamakan dengan yang hakiki.

Pemikiran kedua tokoh muslim di atas menegaskan bahwa spiritualitas hakekatnya merupakan potensi manusia dalam dimensi ruhaniyah. Dimensi ruhaniyah mencakup energi kehidupan yang bersumber dari nur Allah swt yang ditiupkan ke dalam jasad manusia sejak dalam kandungan seorang ibu (HR. Bukhari dan Ahmad ibn Hambal). Setiap manusia sebenarnya sudah ada perjanjian dengan Allah, Zat Pencipta seluruh alam dengan kesaksiannya akan eksistensi Allah swt (lihat dalam QS. al-A'raf:172) dan kelak akan kembali kepadaNya. Kesaksian inilah yang melahirkan konsekuensi ikatan ruhaniyah manusia dengan Allah swt yang diwujudkan dalam fitrah ilahiyah (ketuhanan) dan fitrah insaniyah (kemanusiaan). Kedua fitrah ini merupakan kerangka dasar bangunan etika universal manusia (lihat dalam Ubaidillah, artikel Konseling Reliji, 2010) yang mengutamakan nilai-nilai ketauhidan dan kebajikan. Sebagaimana yang telah tertuang dalam firman Allah mengenai prinsip-prinsip etik manusia untuk berakhlakul karimah, yakni dalam QS al-An'am:151-153, yang mencakup nasehat-nasehat bagi manusia untuk meraih kebahagiaan hidup di dunia dan akherat.

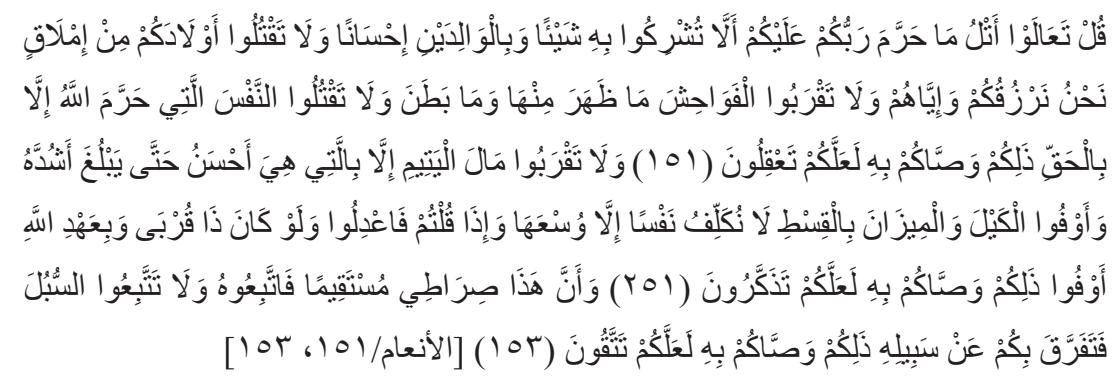

"Katakanlah: "Marilah kubacakan apa yang diharamkan atas kamu oleh Tuhanmu, yaitu: janganlah kamu mempersekutukan sesuatu dengan Dia, berbuat baiklah terhadap kedua orang ibu bapa, dan janganlah kamu membunuh 
anak-anak kamu karena takut kemiskinan. Kami akan memberi rezki kepadamu dan kepada mereka; dan janganlah kamu mendekati perbuatan-perbuatan yang keji, baik yang nampak di antaranya maupun yang tersembunyi, dan janganlah kamu membunuh jiwa yang diharamkan Allah (membunuhnya) melainkan dengan sesuatu (sebab) yang benar". Demikian itu yang diperintahkan oleh Tuhanmu kepadamu supaya kamu memahami (nya). Dan janganlah kamu dekati harta anak yatim, kecuali dengan cara yang lebih bermanfa at, hingga sampai ia dewasa. Dan sempurnakanlah takaran dan timbangan dengan adil. Kami tidak memikulkan beban kepada seseorang melainkan sekedar kesanggupannya. Dan apabila kamu berkata, maka hendaklah kamu berlaku adil kendatipun dia adalah kerabat (mu), dan penuhilah janji Allah. Yang demikian itu diperintahkan Allah kepadamu agar kamu ingat, dan bahwa (yang Kami perintahkan) ini adalah jalan-Ku yang lurus, maka ikutilah dia; dan janganlah kamu mengikuti jalan-jalan (yang lain), karena jalan-jalan itu mencerai-beraikan kamu dari jalan-Nya. Yang demikian itu diperintahkan Allah kepadamu agar kamu bertakwa."

Nilai-nilai luhur yang selalu condong pada kebajikan dengan sesama dan lingkungan alam itu merupakan karakter spiritualitas yang secara filosofis merupakan aktualisasi dari fitrah manusia. Apabila potensi fitrah itu dapat digali dan dikembangkan akan menghasilkan bentuk kecerdasan manusia yang mendasari seluruh sikap, perilaku, dan cara berpikirnya. Oleh karena dimensi spiritual ini merupakan dimensi ruhaniyah yang membutuhkan proses perenungan dan penghayatan yang mendalam, maka aktualisasinya juga memerlukan proses pengasahan dan penajaman serta potensialisasi fungsi-fungsi psikis secara seimbang.

Fungsi psikis dimaksud, misalnya fungsi hati (qalb) yang akan melahirkan daya emosi manusia untuk merespon segala gejala dan fenomena kehidupan manusia. Di dalam hati inilah bersemayam sisi spiritual manusia yang akan mengalami pengalaman puncak sebagai reaksi atas laku ruhaniyahnya. Fungsi psikis lainnya adalah akal yang memproses daya kognisi manusia untuk memahami segala penciptaan dan proses alam sebagai suatu kehendak Yang Kuasa dan diatur sedemikian rupa atas kehendak-Nya. Kemudian fungsi nafs yang 
melahirkan dorongan dan kehendak manusia- yang berpotensi pada kebaikan atau keburukan- untuk dapat dikendalikan dan dikelola sesuai arah fitrah kebaikan manusia, sehingga mencapai tingkatan nafsul muthmainnah (jiwa yang tenang), bukan nafsul ammarah bil suu'.

Dengan demikian, kecerdasan spiritual dengan mengacu pada makna spiritual di atas, merupakan kemampuan manusia dalam mengelola berbagai keadaan secara arif dan sesuai dengan kebutuhan penyelesaian masalah secara tepat dan efektif. Kemampuan tersebut tidak lain sebagai hasil atau efek dari kemampuan menyeimbangkan fungsi-fungsi psikis sesuai dengan potensi fitrah yang telah ada dalam diri manusia.

Secara sederhana kecerdasan spiritual dimaknai sebagai kemampuan individu dalam memahami nilai-nilai dan makna kehidupan yang menjadikannya seorang yang arif, bijak, dan berperilaku di atas kesadaran utuh akan peran dan tanggung jawabnya sebagai manusia yang memiliki hak dan kewajiban baik terhadap diri maupun lingkungannya.

Jauh sebelum berkembangnya kecerdasan spiritual, orang selalu mengidentikkan kecerdasan pada kecerdasan intelektual (IQ). Bahkan kecerdasan intelektual itupun hanya tertuju pada kecerdasan yang sifatnya matematis dan logis, sehingga seorang anak dikatakan cerdas bila ia mampu memecahkan soal-soal matematika atau materi pelajaran yang hanya dijangkau dengan penjelasan akal rasionalnya saja. Kecerdasan hanya dipahami sebatas pada kemampuan akal untuk memaknai suatu fenomena dan memahaminya secara kognitif.

Dalam perkembangan berikutnya, ditemukan bahwa kecerdasan intelektual saja tidak cukup untuk membuat seseorang berhasil dalam hidupnya. Ada kecerdasan lain yang lebih menentukan keberhasilan dan kemampuan seseorang dalam menyesuaikan diri dengan lingkungannya, yakni kecerdasan emosional. Goleman menguraikan bahwa kecerdasan intelektual tidak menjamin seseorang sukses hidupnya ketika kondisi emosionalnya yang tidak stabil (2007:37). Meskipun memiliki nilai IQ yang tinggi, namun ketika pengendalian diri dalam penggunaan emosi rendah, seringkali membuat seseorang gagal dalam hidupnya, misalnya seorang jenius tetapi melakukan kejahatan atau menjadi pecandu minuman keras. Bentuk-bentuk penyelesaian masalah yang menunjukkan ketidakmampuan individu dalam mengelola manajemen emosi ketika dihadapkan pada persoalan hidup. Hanya $20 \%$ saja IQ berkontribusi terhadap kesuksesan seseorang, sementara 80\% merupakan 159 
kontribusi dari kekuatan lain termasuk di dalamnya kecerdasan emosional (Goleman, 2003:44).

Sementara kecerdasan spiritual mulai banyak diperbincangkan setelah adanya penemuan Zohar dan Marshall yang menyatakan bahwa ada kecerdasan spiritual yang dinilai paling utama dalam mendukung keberhasilan hidup seseorang. Kecerdasan spiritual mengantarkan seseorang memiliki nilai luhur kehidupan sehingga mampu memaknai segala pengalaman hidup dibanding hanya sekedar cerdas secara intelektual dan emosional saja. Kecerdasan spiritual menjadi landasan utama individu untuk memaknai kemampuan intelektual dan emosional dalam pengaplikasiannya dalam kehidupan.

Kecerdasan spiritual menurut Zohar dan Marshall, merupakan kemampuan individu dalam menghadapi dan`memecahkan permasalahan dengan memahami makna dan nilainya, sehingga individu tersebut mampu menempatkan sikap dan perilakunya sesuai dengan konteks makna dan nilai dari tindakannya. Zohar dan Marsahll menempatkan kecerdasan spiritual sebagai puncak kecerdasan di atas kecerdasan intelektual dan emosional (2000:4). Seseorang yang cerdas secara spiritual memiliki pandangan jauh ke depan dan luas dengan keyakinan yang kuat bahwa segala sesuatunya memiliki makna dan nilai yang dapat dijadikan pedoman individu dalam mengambil suatu keputusan pilihan tindakan.

Ada lima kriteria individu yang memiliki kecerdasan spiritual, seperti yang dikutip Jalaluddin Rakhmat (2007) menurut Roberts A. Emmons (The Psychology of Ultimate). Pertama, kemampuan untuk mentransendensikan yang fisik dan material. Kemampuan ini mengindikasikan adanya perasaan menyatu antara diri dan alam, sehingga memunculkan sifat peduli dan peka terhadap kondisi diri dan lingkungannya yang membuatnya memahami harus bersikap bagaimana untuk menjaga kedamaian dan kenyamanan lingkungan.

Kedua, kemampuan untuk mengalami tingkat kesadaran yang memuncak. Pengalaman spiritual ini terlalu sulit untuk dibahaskan secara akal rasional, yang jelas ada suatu kenikmatan dan keadaan dimana individu yang mengalami merasa adanya ketenangan jiwa sehingga mampu bersikap arif dalam menghadapi berbagai situasi, misalnya ketenangan hasil dari pengalaman puncaknya setelah istiqomah menjalankan shalat malam, tahajud.

Ketiga, kemampuan untuk mensakralkan pengalaman seharihari, actinia begitu berharga setiap peristiwa, interaksinya dalam berbagai lingkungan, berbagai kenyataan hidup, sehingga individu akan selalu mengambil nilai dan pelajaran yang bisa diambil untuk 
dijadikan sebagai bentuk kesadarannya memahami sebuah realitas kehidupan yang tidak lepas dari impian, upaya, dan kehendak Allah swt.

Keempat, kemampuan untuk menggunakan sumber-sumber spiritual untukmenyelesaikan masalah; dan kemampuan untukberbuat baik. Berbagai pengalaman dan kearifan sikap dalam menghadapi realitas dan mengelola diri akan menjadi bekal individu untuk menyelesaikan permasalahan sehingga tidak jatuh pada tataran emosi atau intelektual saja. Permasalahan dihadapi dengan cara pandang yang luas, obyektif, tegas berpikir, dan arif bersikap, menempatkan permasalahan sesuai dengan kebutuhan penyelesaiannya.

Kelima, memiliki rasa kasih yang tinggi pada sesama makhluk Tuhan. Kemampuan ini didasarkan pada kesadaran akan adanya sifat Maha Rahman dan Rahim Allah terhadap makhluk-Nya. Manusia yang merupakan makhluk ciptaan yang diamanahi sebagai khalifahNya di muka bumi juga telah ada dalam dirinya sifat-sifat Allah, salah satunya adalah kasih sayang yang harus dipantulkan terhadap sesama ciptaan Allah, baik dengan sesama manusia maupun dengan alam. Sebagaimana yang dipaparkan Quraish Shihab bahwa Allah yang Maha Rahman (pemberi rahmat) karena Dia Maha Rahim (memiliki sifat rahmat), maka bagi individu yang mampu menghayatai Maha Rahman dan Rahimnya Allah swt, akan terefleksikan dalam ciri kepribadiannya (1999:24).

Individu yang memiliki kecerdasan spiritual mampu menjadikan pengalaman hidupnya sebagai sesuatu yang selalu bermakna baik dalam aktivitas akademik, sosial, maupun keagamaannya. Bila seorang beragama, maka ia akan menjadi seorang yang berpegang teguh dengan agamanya karena mampu memahami makna dan nilai ajaran agamanya, sementara diapun akan bersikap arif dalam bergaul dengan orang lain yang berbeda agama, sekalipun dengan seorang yang atheis. Hal tersebut karena tindakannya selalu mendasarkan pada prinsip-prinsip kemanusiaan, sosial, dengan tetap melandaskan pada prinsip ajaran agamanya.

Namun perlu diketahui bahwa kecerdasan spiritual tidak identik dengan seorang yang beragama. Seorang yang beragama belum tentu memiliki kecerdasan spiritual, ketika agama yang dipeluknya hanya dipahami sebatas pada pengakuannya sebagai sebuah doktrin ajaran dan rangkaian ritual ibadah yang harus dijalani. Dalam kondisi beragama seperti tersebut tidaklah mengherankan bila banyak ditemukan seorang yang beragama tetapi mengabaikan nilainilai kemanusiaan, melakukan tindakan korup, melakukan tindakan 161 
tiran, dan lebih mengedapankan kepentingan diri dan golongan, atau membenarkan diri dan menganggap diri serta agamanya paling benar, sehingga menolak perbedaan dan keberagaman pendapat atau keyakinan orang dan kelompok lain.

Berbeda dengan seorang yang beragama dan sekaligus memiliki kecerdasan spiritual, akan memahami agamanya secara utuh mencakup makna dan nilai yang terkandung di dalam setiap ajarannya. Dalam tradisi Islam, kecerdasan spiritual sangat dekat hubungannya dengan aspek sufistik yang menjadi inti ajaran Islam, yakni aspek esoteris yang memfokuskan pada upaya mendekatkan diri kepada Allah swt. Islam tidak hanya dipahami sebagai ajaran agama yang harus dijalankan secara syar'i, tetapi juga secara hakiki, sehingga seorang muslim benar-benar akan dapat memahami, menghayati, dan merasakan nikmatnya beribadah kepada Allah swt.

Itulah sebabnya, spiritual dalam Islam dimaknai sebagai aspek yang akan mengantarkan pemahaman dan kesadaran manusia pada hakekat penciptaannya, yakni fitrah manusia sebagai seorang abdullah dan juga sebagai seorang khalifah Allah di muka bumi. Kesadaran pada fitrah penciptaan berarti menyadari bahwa di samping ada kewajiban beribadah kepada Allah juga ada kewajiban berbuat kebajikan dengan sesama manusia dan alam semesta. Berbuat kebajikan di antaranya: memberi maaf, bersyukur atau mengungkapkan terimakasih, bersikap rendah hati, menunjukkan kasih sayang dan kearifan.

Seto Mulyadi mengatakan bahwa kecerdasan spiritual adalah bagaimana manusia dapat berhubungan dengan Sang Pencipta (Ummi, edisi 4, 2002). Kecerdasan spiritual yang berlandaskan pada agama, merupakan kemampuan individu untuk menguatkan kesadaran beragamanya sebagai landasan untuk lebih dekat dengan Allah swt. Kedekatan hubungan tersebut menjadikan individu memperoleh kekuatan spirit atau kekuatan ruhaniyah untuk menyingkap makna dibalik gejala dan fenomena sehingga memampukan individu menempatkan sikap dan perilaku dalam berbagai situasi. Meskipun terkadang pilihan tindakannya tanpa melalui proses pemikiran panjang atau bahkan di luar jangkauan akal rasio manusia.

Perlu ditegaskan bahwa spiritualitas merupakan dimensi internal yang sudah ada dalam diri setiap manusia, seperti yang telah dipaparkan di atas tentang konsep spiritual dalam Islam. Semenntara agama merupakan seperangkat aturan dan kepercayaan formal yang dibebankan pada setiap pemeluknya. Meskipun di dalam ajaran agama tersebut mencakup nilai-nilai suci yang akan menghubungkan manusia dengan Tuhannya, namun kebanyakan para pemeluk hanya memahami 
agama dari sisi luarnya saja (hasil penelitian Gordon Allport, dalam Zohar dan Marshall, 2002), sebagaimana pengertian agama itu sendiri. Ada pesan spiritual dalam agama yang belum tersentuh dan terasakan dalam jiwa para pemeluknya. Kenyataan tersebut dapat dilihat dalam fenomena masyarakat beragama yang masih banyak ditemukan peristiwa yang mengabaikan nilai ketauhidan, kemanusiaan, dan keseimbangan alam.

Di sinilah pentingnya, mengkaji kembali makna agama, khususnya agama Islam sebagai seperangkat ajaran yang akan menghidupkan fitrah spiritual manusia dalam perilaku ibadah dan kesehariannya. Karena sifatnya potensial, maka proses bimbingan dan pendidikan untuk menanamkan nilai-nilai agama terhadap anak menjadi aktivitas yang sangat penting untuk mengaktualkan petensi kecerdasan spiritual tersebut.

\section{Potensi Kecerdasan Spiritual pada Anak}

Kecerdasan spiritual disebut sebagai salah satu potensi dikarenakan telah ada dalam setiap diri manusia kemampuan-kemampuan yang akan menjadikannya cerdas baik secara intelektual, emosional, maupun spiritual. Namun dalam realisasinya, potensi tersebut membutuhkan upaya penggalian dan pengembangan, misalnya melalui proses pendidikan.

Setiap anak yang terlahir ke muka bumi, difirmankan oleh Allah swt, belum memiliki pengetahuan apapun, tetapi baginya telah dianugerahi pendengaran, penglihatan, dan hati (QS. an-Nahl:78). Pendengaran, penglihatan, dan hati hakekatnya merupakan piranti yang dianugerahkan Allah kepada manusia sebagai alat untuk menggali dan mengembangkan segala potensi yang sebenarnya sudah ada dalam setiap penciptaan manusia. Dan, kecerdasan spiritual ini termasuk sebagai potensi semestinya dapat mulai diasah dan diaktifkan sedini mungkin. Sebagai sebuah potensi, kecerdasan spiritual sangat memerlukan berbagai upaya yang akan memunculkan kesadaran spiritual sehingga seorang anak akan tumbuh menjadi manusia dewasa yang memahami segala pengetahuan dan pengalaman hidupnya dalam cakupan makna dan nilai secara luas.

Seorang anak yang sedang dalam masa perkembangan memiliki besar kemungkinan dapat diarahkan untuk menjadi pribadi dewasa yang berkecenderungan ke arah positif atau ke arah negatif. Hal ini didasarkan pada kecenderungan jiwa manusia yang akan selalu dihadapkan pada dua pilihan, ke arah kebajikan atau ke arah kefasikan (tercantum dalam QS. as-Syams:7-8). Oleh karenanya, penting 
untuk diperhatikan oleh para orang tua atau para pendidik untuk mempotensikan kecenderungan anak pada kebajikan yang hakekatnya merupakan upaya mengaktualkan potensi spiritual anak.

Telah dijelaskan di atas bahwa potensi spiritual merupakan sumber potensi yang melahirkan dorongan-dorongan untuk berbuat kebajikan. Dalam konteks inilah nilai penting aktualisasi potensi kecerdasan spiritual pada anak. Jalaluddin Rahmat telah memaparkan dalam bukunya tentang pengembangan kecerdasan spiritual (SQ spiritual quotion) pada anak, bahwa setiap anak hakekatnya memiliki kemampuan untuk mempotensikan aspek spiritualnya, namun seringnya orang-orang dewasa di sekitarnya tidak memahami akan keberadaannya. Misalnya seorang anak yang baru berusia tiga tahun, sebenarnya sudah mengetahui suatu perbuatan tertentu baik atau tidak baik, seorang anak empat tahun yang sudah menunjukkan rasa kasihnya kepada seorang peminta-minta. Umumnya hal itu dianggap biasa saja dan diabaikan, tetapi sebenarnya sikap tersebut merupakan benih-benih spiritual anak yang masih sangat membutuhkan penajaman, sehingga akan terbentuk menjadi sifat dan karakter anak ketika sudah dewasa.

Hadits Rasulullah Muhammad saw tentang fitrah, bahwa seorang anak yang terlahir dalam keadaan suci (HR. Bukhari dan Muslim), tidak semata dipahami sebagai keadaan anak yang bersih dan suci dari dosa warisan dan hal-hal negatif lainnya saja. Tetapi juga dapat dimaknai bahwa setiap anak yang terlahir telah membawa fitrah yang kelak akan membuatnya memiliki kebutuhan untuk mengenal dan dekat dengan Tuhannya. Dalam berbagai wacana Islam, fitrah tersebut kemudian sering diistilahkan dengan fitrah agama. Hadits ini juga dapat direlasikan dengan ayat Allah swt dalam QS. Fathir: 30, bahwa tidak ada perubahan pada fitrah Allah, yakni fitrah agama yang lurus bagi semua manusia, tetapi kebanyakan manusia tidak mengetahuinya.

Fitrah agama yang lurus dimaksudkan sebagai jalan yang akan mengantarkan manusia pada kesadaran kebutuhannya untuk mengenal dan dekat dengan Allah swt sehingga akan terbuka pintu hati dan akalnya untuk membaca segala gejala dan fenomena alam sebagai suatu penciptaan untuk menjadi sarana komunikasi manusia dengan Tuhannya. Melalui kesadaran akan fitrahnya, manusia akan mengetahui bagaimana ia berkomunikasi dengan Allah baik melalui pertemuan langsung dengan-Nya maupun melalui interaksi dengan sesama manusia dan dengan lingkungan alam.

Kemampuan untuk memahami fitrah dan aktualisasinya dalam kehidupan inilah yang semestinya sudah mulai diasah dalam diri 
seorang anak. Anak dalam konteks di sini adalah yang masih dalam tanggung jawab penuh orang tua, masih dalam masa bimbingan dan pendidikan, yakni pada masa pra sekolah hingga usia sekolah (antara usia 2-15 tahun). Penulis menekankan pada usia tersebut karena sepanjang rentang usia tersebut merupakan masa-masa anak mengenal segala hal yang baru dan kecenderungan besarnya rasa ingin tahu terhadap perubahan dan perkembangan baik mengenai diri maupun lingkungannya (lihat dalam Hurlock, 1991).

Bila dihayati makna keberadaan rasa ingin tahu (curiosity) pada diri anak, sebenarnya merupakan anugerah Allah swt dalam bentuk dorongan (motif) keingintahuan manusia karena sudah adanya piranti atau wadah yang akan menempatkan suatu pengetahuan ke dalamnya. Termasuk aspek spiritual manusia yang secara psikis sudah Allah sediakan dalam piranti qalb (hati). Bagian hati terdalam yang dalam istilah Mubarok (2002:31) sebagai bashirah, mata hati atau mata batin (hati nurani) yang menjadi sumber kejujuran dan pengakuan manusia akan sebuah kebenaran hakiki. Melalui hati nurani itulah manusia sebenarnya mengetahui akan nilai-nilai kebenaran, kejujuran, kemanusiaan, dan juga nilai-nilai ketuhanan. Itulah nilai-nilai spiritual yang akan menjadi kekuatan jiwa/batin manusia untuk mampu membuka tabir keburukan yang akan menjadi penghalang dalam berkomunikasi dengan Allah swt, sebagai pencipta seluruh alam.

Sisi spiritual merupakan dimensi non-materi yang akan menjadikan keseimbangan jiwa manusia, di antara sisi intelektual, emosional, dan fisikalnya. Khalil A Khavari (2000:23) menyebutkan dimensi spiritual ini sebagai dimensi non-material jiwa manusia yang pada umumnya belum terasah. Ibarat sebuah intan yang harus digosok untuk memunculkan keindahannya, sehingga akan terpancar dalam kepribadian yang arif dan mampu mencapai kebahagiaan baik di dunia maupun di akherat. Itulah sebabnya, potensi kecerdasan spiritual akan tampak ke permukaan kepribadian manusia dewasa jika sudah diupayakan dalam proses pendidikan yang mengarah pada pengasahan, pembiasaan, pengenalan, dan penguatan aktualisasinya dalam memahamkan segala gejala dan fenomena kehidupan.

\section{Pendidikan Agama sebagai Sarana Pendampingan dalam Mempotensikan Kecerdasan Spiritual Anak}

Kecerdasan spiritual tidak identik dengan keberagamaan individu, akan tetapi keberagamaan yang dikuatkan dengan kecerdasan spiritual akan menjadikan individu pemeluk agama lebih menghayati dan memahami makna agama bagi diri dan kehidupannya. Bahkan semestinya para 
pemeluk agama lebih akan merasakan pengalaman spiritual yang mendalam karena praktek-praktek dalam ajaran agama mengajarkan cara dan menunjukkan jalan menuju diri yang terdalam hingga menjangkau Zat Pencipta yang terpantul dalam diri setiap makhlukNya. Menurut Rahmat dalam tulisan pengantarnya menjelaskan bahwa praktek-praktek keagamaan mengajarkan para pemeluknya untuk menyambungkan diri dengan bagian diri yang terdalam (2002:xxvi).

Seperti halnya dalam ajaran tasawuf yang menekankan pada pamahaman Islam secara utuh komprehensif, baik dari sisi syar'iyah maupun hakikatnya, dari sisi fiqh maupun sisi akhlaknya. Dengan pemahaman inilah, seorang muslim akan merasakan inti ajaran Islam yang hakekatnya membangun kesadaran dan jalan komunikasi dengan Allah swt. Jalan komunikasi tersebut dapat melalui beragam cara, misalnya dalam komunikasi ritual ibadah langsung dengan Allah (shalat, puasa, zakat, haji), berbuat, kebajikan, menuntut ilmu dan pemahamannya, dan dalam segala aktivitas yang senantiasa mencari ridla-Nya. Masing-masing cara tersebut tidak hanya dilaksanakan sebagai sebuah ritual atau sebagai proses adaptasi dengan lingkungan semata, tetapi memilki tujuan pencarian makna sehingga akan menemukan kehidupan yang berarti (the meaning of life). Inilah yang menjadi karakteristik dari jalan spiritual dalam Islam.

Keberadaan dimensi spiritual dalam diri anak dan kehadiran agama dalam kehidupan, dapat diintegrasikan dan akan saling mendukung untuk terbentuknya keseimbangan kepribadian seorang muslim. Dengan adanya potensi spiritual dalam diri setiap anak, didukung dengan kebutuhan pendidikan agama bagi anak maka pendidikan agama tersebut semestinya akan menjadi sarana para orang tua ataupu para pendidik pada umumnya untuk mengembangkan potensi kecerdasan anak.

Pendidikan agama merupakan bidang pendidikan awal yang harus diberikan kepada anak. Mengacu pada makna pendidikan menurut al-Ghazali, sebagai sebuah proses penanaman nilai yang akan mengantarkan anak untuk mengenal dan dekat dengan Allah swt. Pendidikan harus memberikan arah kepada anak bahwa segala pengetahuan dan bidang keilmuan apapun yang kelak ditekuni tidak akan terlepas dari kegiatan secara sadar untuk mencapai pengenalannya kepada Allah swt (ma'rifatullah). Untuk itu, pendidikan agama menjadi prioritas utama dalam pendidikan awal terhadap anak, sementara pendidikan dalam kategori disiplin ilmu yang lebih bersifat material atau keterampilan merupakan alat yang akan melengkapi pemahaman anak terhadap penciptaan dan eksistensi Allah swt (lihat 
dalam Sulaiman, 1990).

Konsep pendidikan dalam Islam juga telah ditemukan dalam nasehat Luqman terhadap putranya yang tertera dalam QS Luqman:13-19. Pendidikan awal yang sekaligus akan menjadi benteng tauhid anak, yakni menanamkan pada anak untuk tidak menyekutukan Allah swt. Pendidikan untuk tidak berbuat musyrik ini memiliki makna yang cukup luas. Secara garis bear dapat dijelaskan bahwa sebagai seorang abdullah, tidak ada kekuatan atau kekuasaan lain yang patut disembah atau diagung-agungkan kecuali hanya kepada Allah swt. Nilai ketauhidan ini akan membekali anak untuk tidak gugup menghadapi beragam kekuasaan baik jabatan, harta, maupun kedudukan, semuanya hanyalah sarana atau alat untuk memahami kekuasaan dan kehendak Allah terhadap apa yang terjadi pada hamba-Nya.

Selanjutnya, dalam al-Quran surat Luqman juga mencakup pendidikan untuk berbuat kebajikan baik kepada orang tua, sesama manusia, berbuat jujur, rendah hati, sabar, serta tidak angkuh, sombong. Nilai-nilai pendidikan ini akan menjadi kerangka dasar nilainilai spiritual yang penting untuk ditanamkan dalam diri anak. Di saat anak mengeksplorasikan rasa keinginatahuannya (sisi intelektual), mengungkapkan perasaannya (sisi emosional), dan mengungkapkan kejujuran, kepolosan, rasa kasih, serta pantulan kebahagiaan (sisi spiritual) dalam perilaku kesehariannya, dapat dijadikan momenmomen untuk menjelaskan makna dari setiap peristiwa.

Menarik untuk menyimak kiat-kiat mengembangkan kecerdasan spiritual (SQ) anak menurut Rakhmat (2007), yakni:

a. Jadilah kita "gembala spiritual" yang baik,

b. Bantulah anak untuk merumuskan "missi" hidupnya,

c. Baca kitab suci bersama-sama dan jelaskan maknanya dalam kehidupan kita,

d. Ceritakan kisah-kisah agung dari tokoh-tokoh spiritual,

e. Diskusikan berbagai persoalan dengan perspektif ruhaniah,

f. Libatkan anak dalam kegiatan-kegiatan ritual keagamaan,

g. Bacakan puisi-puisi, atau lagu-lagu yang spiritual dan inspirasional,

h. Bawa anak untuk menikmati keindahan alam,

i. Bawa anak ke tempat-tempat orang yang menderita, dan

j. Ikut-sertakan anak dalam kegiatan-kegiatan sosial.

Sepintas, kiat-kiat pengembangan spiritualitas anak di atas masih bersifat universal, belum spesifik yang mengarah pada pengembangan kecerdasan spiritual dalam konteks pendidikan 167 
agama. Oleh karenanya, di sini ada hal yang perlu diperhatikan dalam memaknai kegiatan pendidikan agama terhadap anak sebagai sarana untuk mengembangkan kecerdasan spiritualnya. Bahkan pendidikan agama yang diiringi dengan tujuan potensialisasi kecerdasan spiritual ini akan lebih memahamkan anak pada penghayatan nilai ajaran Islam yang tidak terbatas pada tujuan ketaatan menjalankan ibadah saja, tetapi juga penghayatan akan nilai dan cakupan makna terdalam dalam setiap laku ibadahnya.

Secara ringkas, kiat-kiat di atas dapat penulis paparkan sebagai penjelas dari masing-masing poin. Pertama, menjadi penggembala spiritual dimaksudkan bahwa seorang pendidik harus menjadi pribadi yang juga mengondisikan diri sebagai seorang yang mengembangkan daya spiritualitasnya. Pengkondisian diri sebagai seorang yang selalu ingin menguatkan spiritualitasnya akan menjadi kekuatan internal untuk menarik perhatian anak mengikuti arahan dan bimbingan pendidik. Dalam konsep pendidikan al-Ghazali yang ditulis Sulaiman, menyebut seorang pendidik adalah seorang guru ruhani. Disebut sebagai guru ruhani dalam konteks pendidik tersebut menjadikan tujuan pendidikan agama sebagai tujuan yang berorientasi pada relijiusetik, pendidikan yang berlandaskan pada dasar sufistik, mengantarkan anak (peserta didik) untuk mengenal dan dekat dengan Allah swt.

Kedua, seorang anak harus sudah dibiasakan untuk memaknai setiap tindakannya dengan memahamkan apa dan tujuannya dalam mengambil suatu pilihan tindakan, sehingga langkahnya jelas karena ada tujuan dan makna yang ingin dicapai (vissioner). Misalnya tujuan anak untuk sekolah, apa yang ingin diraih setelah melakukan suatu kegiatan, termasuk apa yang ingin dicapai dalam kehidupan ke depan (cita-cita dan tujuannya).

Ketiga, dalam pendidikan agama Islam pengenalan dan latihan membaca kitab suci al-Quran merupakan materi utama yang harus dikuasai anak. Selama ini anak yang sedang belajar membaca al-Quran cenderung pada penguasaan baca tulis (BTA) saja serta hafalan. Sudah semestinya dijelaskan pula arti dan maksud dari ayat-ayat al-Quran serta kontekstualisasinya dalam aktivitas sehari-hari. Secara perlahan kegiatan ini akan membentuk akhlak al-Quran dalam diri anak.

Keempat, anak pada umumnya senang mendengarkan cerita terutama anak dalam usia pra-sekolah hingga usia sekolah dasar. Menceritakan kisah-kisah teladan yang mengandung nilai spiritualitas akan membantu anak memahami nilai-nilai kehidupan. Bahkan jika anak menyenangi cerita film kartun pun, seorang pendidik harus mampu menyampaikan sisi mana yang memiliki nilai kehidupan yang 
sesuai dengan ajaran agama Islam.

Kelima, membiasakan membahas dan mendiskusikan persoalan dengan anak secara rasional akan melatih anak berpikir logis dan obyektif. Jika dikuatkan dengan perspektif ruhaniyah akan membangkitkan sisi spiritual anak untuk membantunya membangun mental yang sehat dan seimbang antara pemahaman rasional dan spiritualnya.

Keenam, melibatkan anak dalam kegiatan-kegiatan ritual keagamaan dapat dijadikan sebagai kegiatan pembiasaan dan pelatihan mental untuk memiliki ikatan dengan Allah swt. Misalnya mengajak shalat berjamaah, mengajak anak menjalankan ibadah puasa baik wajib maupun sunnah, membagikan zakat, dan bersama membaca al-Quran, bahkan memberi kepercayaan kepada anak untuk memimpin doa setelah shalat. Melalui keterlibatan anak dalam aktivitas keagamaan akan membantu anak mengenal diri dan potensinya.

Ketujuh, setiap anak memiliki potensi seni dan keindahan. Membacakan karya-karya seni, baik dalam bentuk puisi, cerita, lagu, musik, lukisan, gambar, merupakan salah satu metode bimbingan untuk memunculkan daya imajinasi dan kreatifitas anak. Untuk tujuan potensialitas kecerdasan spiritual, arahkan pembacaan dan penunjukkan hasil karya seni yang bernuansa spiritual, misalnya puisi tentang penciptaan alam, puisi sufistik, atau bersama dengan memvariasikan nada membacakan syai-syair shalawat nabi dan bermunajat kepada Allah. Kemudian diselingi dengan penjelasan maksud dan tujuan dari apa yang dibacanya. Hal ini akan memberikan kontribusi referensi pada memori anak untuk menyentuh sisi terdalamnya.

Kedelapan, sesekali anak juga membutuhkan menghirup udara di alam terbuka yang masih alami, agar anak tidak hanya mengenal dunia glamor dan penuh rekayasa manusia yang kering dari nilai alamiah. Melalui pembelajaran alam anak dibimbing memahami bahwa ada hak alam dan lingkungan yang harus diperhatikan manusia untuk menciptakan keseimbangan alam kedamaian dalam hidup. Inilah sisi kehidupan manusia dalam menjalankan tugasnya sebagai khalifah Allah di bumi.

Kesembilan, anak juga harus dikenalkan dengan sisi kehidupan yang tidak akan lepas dari dua sisi, kebahagiaan dan penderitaan, keberuntungan dan ketidakberuntungan, kesuksesan dan kegagalan, atau kehidupan komunitas yang tercukupi dan yang tidak tercukupi. Masing-masing perlu dijelaskan secara filosofis apa yang membuat orange senang, sedih, bahagia, menderita, atau merasa gagal, bahkan 
dapat dicontohkan kondisi-kondisi tersebut dalam realitas kehidupan. Jadi, anak dilatih untuk memahami berbagai situasi kehidupan dengan latar belakangnya, agar anak dapat mengambil sikap di saat dihadapkan pada situasi tertentu baik mengenai diri maupun orange lain.

Kesepuluh, tegaskan pada anak bahwa keikutsertaannya dalam kegiatan sosial bukan untuk dilihat atau dipuji. Akan tetapi sebagai bentuk kepedulian dan kepekaan sosial yang hal itu sudah merupakan kewajiban dan kebutuhan rasa sosial setiap manusia. Jika pemahaman ini ditekankan, maka kebahagiaan diri yang hakiki akan tercapai bila telah teraktualnya jiwa sosial dalam setiap jiwa manusia.

Mengenai metode dan cakupan materi dapat disesuaikan dengan tahapan usia perkembangan anak dan kebutuhannya. Tentu akan berbeda antara anak usia pra-sekolah yang masih didominasi dengan kesenangannya bermain dengan anak usia kanak-kanak akhir yang sudah mengenal arti kedisiplinan dan kebutuhan keseriusan dalam mempelajari berbagai ilmju pengetahuan. Sebagaimana halnya dalam pendidikan secara umum, berbagai metode dapat dikembangkan dengan tetap mengacu pada pemaknaan materi pendidikan, baik dalam memahamkan nilai Islam, iman, maupun ihsan. Ketiganya merupakan aspek pendidikan Islam yang akan membekali anak memahami agama Islam secara komprehensif: adanya keimanan dan keyakinan yang kuat (rukun iman), adanya bentuk ketundukan dan ketaatan sebagai realisasi keimanannya (rukun Islam), dan adanya keyakinan dan kesadaran penuh akan kehadiran Allah swt dalam setiap gerak dan langkahnya (ihsan).

Kiat-kiat di atas dapat diaplikasikan untuk mengisi berbagai aktivitas dalam proses pendampingan anak untuk menerima pengetahuan agama Islam. Banyak nilai yang dapat diambil pelajaran dalam setiap proses kehidupan yang dapat direlasikan dengan nilainilai dalam ajaran Islam. Misalnya melalui kisah-kisah teladan baik tentang kehidupan Rasulullah Muhammad saw, kehidupan para sahabat, ulama besar, para kekasih Allah yang akan menjadi sumber inspirasi anak untuk menumbuhkembangkan spiritualitasnya.

Namun, berbagai upaya di atas tentu tidak lepas dari kepribadian pendidik itu sendiri. Sebagai pendidik, ada hal utama yang juga harus diperhatikan, yakni pendidik adalah sekaligus pelaku dalam proses aktualisasi potensi kecerdasan spiritual. Faktor inilah yang juga akan menjadi kunci tersampaikannya pesan pendidikan. Kecerdasan spiritual seorang pendidik akan memudahkan pendidik memahami dan memaknai setiap tahap perkembangan anak dan kebutuhannya. Dengan demikian pendidik akan tepat mengambil tindakan dan 
keputusan dalam hal materi yang akan disampaikan, metode yang akan digunakan, dan pendekatan apa yang akan disesuaikan dengan kondisi perkembangan anak.

\section{Simpulan}

Pada akhir tulisan ini, penulis akan menyimpulkan bahwa kecerdasan spiritual akan menjadi penyempurna pencapaian kecerdasan intelektual dan emosional, sehingga terbentuk kepribadian yang seimbang. Dalam konteks pendidikan, dapat dijelaskan bahwa kecerdasan intelektual akan membuat anak mampu memahami dan menyerap informasi dan pengetahuan serta pengaplikasiannya sesuai konteks kebutuhannya. Kecerdasan emosional akan membuat anak mampu mengelola emosinya untuk kebutuhan penyesuaian diri terhadap lingkungan dan berbagai situasi. Sementara kecerdasan spiritual akan membuat anak mampu memaknai setiap keadaan sehingga tahu bagaimana harus bersikap dan berperilaku secara arif dalam berbagai situasi dan keadaan realitas yang dihadapinya.

Pendidikan agama memberikan ruang pembelajaran anak dalam memahami eksistensi Allah swt dan keberadaan manusia sebagai makhluk ciptaan-Nya yang memiliki tugas untuk beribadah. Sudah saatnya bagi para orang tua dan para pendidik untuk menanamkan nilai-nilai agama sebagai dasar rujukan utama mengenal nilai-nilai kemanusiaan, nilainilai ilahiyah dan relevansinya dalam berkehidupan bermasyarakat. Nilainilai itulah yang akan membentangkan potensi kecerdasan spiritual anak, sehingga dalam kondisi zaman yang bagaimanapun, tidak akan gugup dan gegap menyikapinya. Kecerdasan spiritual yang terpotensikan dengan baik akan menguatkan potensi intelektual dan emosional, sehingga benarbenar menemukan makna kehidupan sebagaimana yang telah dicapai oleh para salik, para kekasih Allah ta'ala yang telah meneladani Rasulullah Muhammad saw dalam pencapaian pengalaman puncak spiritualitasnya. 
Yuliyatun

\section{Daftar Pustaka}

Al-Quran dan Terjemahan.

Chaplin, J.P. 2004. Kamus Lengkap Psikologi. Jakarta: Raja Grafindo Persada.

Goleman, Daniel. 2007. Kecerdasan Emosional. terj. T. Hermaya. Jakarta: Pustaka Gramedia Utama.

Hurlock, Elizabeth B. 1991. Psikologi Perkembangan: Suatu Pendekatan Sepanjang Rentang Kehidupan. terj. Istiwidayanti. Jakarta: Erlangga.

Khavari, Khalil A, 2000. Spirtual Intelligence: A Practical Guide to Personal Happiness. New Liskeard: White Mountain Publications.

Mubarok, Achmad. 2002. al Irsyad an Nafsiy, Konseling Agama, Teori dan Kasus. Jakarta: PT Bina Rena Pariwara.

Mujib, Abdul dan Jusuf Mudzakkir. 2002. Nuansa-nuansa Psikologi Islam. Jakarta: Rajawali Press.

Mulyadi, Seto. 2000. Majalah Ummi Edisi 4.

Rahmat, Jalaluddin. 2007. SQ: Mengembangkan Kecerdasan Spiritual Anak Sejak Dini. Bandung: Mizan.

Rakhmat, Jalaluddin. 2002. Kata Pengantar SQ: Memanfaatkan Kecerdasan Spiritual dalam Berpikir Integralistik dan Holistik untuk Memaknai Kehidupan. Karya Danah Zohar dan Ian Marshall, terj. Rahmani Astuti dkk. Bandung: Mizan.

Ruslan,H.M. 2008. Menyingkap rahasia spiritualitas Ibnu 'Arabi. Cet. I; Makassar: Al-Zikra.

Shihab, Quraish. 1999. Menyingkap Tabir Ilahi. Jakarta: Lentera Hati.

Sulaiman, Fathiyah Hasan. 1999. Konsep Pendidikan al-Ghazali. Jakarta: P3M.

Ubaidillah. 2010. "Fitrah dan Potensi Insani dalam Ilmu Tasawuf (Perspektif Terapi Psikologis dan Bimbingan Konseling)". Jurnal Konseling Religi, Vol 1, No. 1, Januari-Juni 2010.

Zohar, Danah, Ian Marshall. 2000 SQ: Spiritual Intelligence the Ultimate Intellegence. Soho Square London: Vloomsbury Publishing. 2002.SQ: Memanfaatkan Kecerdasan Spiritual dalam Berpikir Integralistik dan Holistik untuk Memaknai Kehidupan. Karya Danah Zohar dan Ian Marshall, terj. Rahmani Astuti, dkk. Bandung: Mizan. 